\title{
7 THE DYNAMIC IN EAST ASIAN TRADE
}

\section{Ligang Song, Tina Chen and Shiji Zhao}

Trade has been a key component in the successful story of East Asian development since the region embarked on its modernisation drive in the 1960s. Through trade and the associated export-oriented strategy and regional economic cooperation, the East Asian economies have been connected closely with each other in climbing up the ladder of development, led first by Japan, the newly industrialising economies (NIEs), and then ASEAN, China, Vietnam, India and other South Asian countries. As a result, within a half century, the East Asia as a whole has changed from a peripheral region to one of the most dynamic and highly integrated economies in the world. The East Asian share of world trade increased from 14 per cent in 1980 to about 20 per cent in 2003, equivalent to the share of North America in world trade (Table 7.1). This has been achieved despite some negative external shocks such as oil crisis in the 1970s and exchange rate volatility, difficulties in restructuring their domestic economies, including financial opening of their economies since the 1980s, and the painful experience of the financial crisis in the mid 1990s.

The East Asian experiences demonstrated the feasibility and viability of alternative trade policies: it was no longer possible to associate comparative 


\begin{tabular}{lcccc}
\hline Table 7.1 & Share of world trade by region, & 1980-2003 & (per cent) \\
\hline & 1980 & 1990 & 2000 & 2003 \\
East Asia & 14.1 & 18.7 & 22.7 & 19.9 \\
Japan & 7.0 & 7.4 & 6.4 & 5.7 \\
NIEs & 4.3 & 7.8 & 10.2 & 6.6 \\
ASEAN-4 & 2.3 & 2.7 & 3.7 & 3.8 \\
China & 1.0 & 1.7 & 3.5 & 4.9 \\
Australia, New Zealand & 1.4 & 1.4 & 1.3 & 1.3 \\
North America & 16.8 & 17.7 & 22.3 & 20.5 \\
United States & 12.3 & 13.1 & 15.4 & 14.4 \\
Canada & 3.6 & 3.7 & 4.2 & 3.9 \\
Mexico & 0.9 & 0.9 & 2.8 & 2.2 \\
South America & 2.8 & 1.7 & 2.0 & 1.9 \\
European Union & 41.0 & 44.0 & 35.4 & 37.7 \\
Rest of world & 23.9 & 16.5 & 16.2 & 18.6 \\
\hline
\end{tabular}

Notes: NIEs: Korea, Taiwan, Singapore and Hong Kong; North America: the United States, Canada, Mexico; East Asia: Malaysia, Hong Kong, Indonesia, Japan, South Korea, China, Taiwan, Singapore, and the Philippines; Singapore is included in NIEs, not ASEAN; South America: Argentina, Brazil, Chile, Haiti, and Venezuela.

Sources: International Monetary Fund, Direction of Trade, Washington, DC; International Economic Databank, The Australian National University, Canberra.

advantage with reliance on primary commodity exports. And these experiences certainly put to rest the mistaken belief that developing countries relying on the international market would forever be specialised in the production of primary commodities. These experiences also put an end to the belief that developing countries could not develop rapidly when relying on integration with the international economy as 'a developing country could achieve industrialisation without relying on domestic markets to absorb almost all additional output. ... That demonstrated the fallacy of the earlier view that industrialisation could take place only through import substitution' (Krueger 1997:17).

The East Asian experience has thus stimulated some to attempt to identity the 'dynamic' factors in exporting. Das (1998) stated that looking back three decades, one finds that in several Asian economies, the structural transformation has been more or less fundamental, in that these economies have experienced a dynamic process of changing comparative advantage. 
This entailed a rapid growth in their exports of manufactures as well as a changing structure of manufactured exports. This echoes the view by Krueger (1997) that there appears to be widespread agreement in the 1990 s that the benefits of an open trade regime are largely 'dynamic' in nature, and go well beyond the gains from trade under 'static' models of an open economy.

While a variety of factors, such as technology and foreign direct investment (FDI), have contributed to the achievement of the dynamic gains from trade by the regional economies, an important element of the whole process is the so-called 'institutional integration' which, as defined in Drysdale (1988), refers to the legal agreements and institutional arrangements which facilitate economic exchange among a community of nations. Institutional integration matters as institutional and market integration involves an important two-way interaction, in which close economic ties and common economic problems set the requirements for institutional arrangements, and institutional arrangements influence the degree of economic and political cohesion' (Drysdale 1988:35).

According to Drysdale (1988), low institutional, political and other resistances to trade interact with low transport and communications resistances to generate high intensities in trade and other economic relations. The argument is relevant to the East Asian model for dynamic resource allocation and international specialisation in that if 'there are institutional and legal barriers to trade and capital movements but market ties survive, market integration is frustrated by the lack of institutional integration' (Drysdale 1988:35).

For example, a characteristic of the trade expansion of the newly industrialising economies (NIEs), ASEAN and China resulting from the changing pattern of their respective comparative advantage is the process of their taking over market shares from Japan first in textiles and other labour-intensive manufactured goods, and then from one another: '[a] rrangements that discriminate against their trade growth in favour of established traders would adversely affect their trade and development ambitions and regional trade interests' (Drysdale 1988:21).

This chapter looks into the changing pattern of production and trade and the extent of integration in East Asia in comparison with other major 
regional groups, and discusses the impacts and implications of China's rising trade on the regional economy and economic cooperation. It points out possible future directions in terms of different forms of 'institutional integration' that the regional economies are likely to take and how these alternatives may affect the prospects of East Asian trade and economic growth in the long run.

\section{Changing structure of East Asian production and trade}

Basic trade theory suggests that countries with higher ratios of labour to natural resources and capital to labour will have a strong comparative advantage in manufactures vis-à-vis primary production and exports. Such theory also predicts that comparative advantage in manufactures will grow more rapidly the faster the rate of growth of capital to labour ratio relatively to growth in the rest of the world. As a result, the product composition of exports would shift from a predominance of natural resource intensive exports to unskilled labour intensive exports, further to physical and human capital intensive exports, and then on to technology and knowledge intensive exports (Garnaut and Anderson 1980; Song 1996a; Das 1998).

Table 7.2 presents the changing structures of production of the regional economies from 1970 to 2002 that have a direct bearing on the trade structure of these economies. First, the agricultural sector in all the reported groups of Asian economies including South Asia has dramatically declined. As expected, this change is most visible in NIEs where its share fell steadily from 17 per cent to only three per cent of GDP over the 1970-2002 period. Their share of industry in GDP rose from the 1970s to 1980s, and then declined over the 1990s as the services sector expanded which accounted for 63 per cent of GDP in 2002.

Similarly, ASEAN economies experienced a substantial fall in the share of agriculture, however, unlike in NIEs, the share of their industries continued to rise reflecting the fact that ASEAN's level of economic maturity is less than that in NIEs (Das 1998). Compared to NIEs, ASEAN's services sector had a much lower share of GDP. The agricultural sector in China has fallen quite dramatically especially in the 1990s, but is still higher than that in ASEAN. The industrial sector continued to dominate 
Table 7.2 Changing structure of production, 1970-2002 (per cent of GDP)

\begin{tabular}{|c|c|c|c|}
\hline & Agriculture & Industry & Service \\
\hline \multicolumn{4}{|l|}{ Newly industrialising economies } \\
\hline 1970 & 17 & 33 & 51 \\
\hline 1980 & 9 & 40 & 51 \\
\hline 1990 & 6 & 41 & 53 \\
\hline 2002 & 3 & 34 & 63 \\
\hline \multicolumn{4}{|l|}{ ASEAN-4 } \\
\hline 1970 & 34 & 25 & 41 \\
\hline 1980 & 25 & 36 & 39 \\
\hline 1990 & 19 & 39 & 42 \\
\hline 2002 & 13 & 43 & 44 \\
\hline \multicolumn{4}{|l|}{ China } \\
\hline 1970 & 34 & 38 & 28 \\
\hline 1980 & 31 & 47 & 22 \\
\hline 1990 & 27 & 42 & 31 \\
\hline 2002 & 15 & 51 & 34 \\
\hline \multicolumn{4}{|l|}{ South Asia } \\
\hline 1970 & 45 & 21 & 35 \\
\hline 1980 & 37 & 25 & 38 \\
\hline 1990 & 32 & 27 & 42 \\
\hline 2002 & 23 & 26 & 51 \\
\hline
\end{tabular}

Note: NIEs in 2002 did not include Taiwan.

Source: World Bank, World Development Indicators, Washington, DC.

the Chinese economy, accounting 51 per cent of GDP in 2002, a level that was not matched by NIEs during the period of rapid growth in the 1980s. The expansion of the services sector in China has been less than that in NIEs and ASEAN. South Asian economies have a relatively higher share of agriculture and lower share of industries in GDP. This fact indicates that South Asian economies have been on the lower rung of the development ladder with a slower pace of industrialisation, although these economies have been undergoing structural changes over the period under study.

The structural changes taking place in the East Asian economies is also reflected in the rising shares of exports of manufactures in total exports 
(Table 7.3). The significance of rising shares of exports of manufactures lies in the fact that the relationship between exports of manufactures and high TFP growth may well be the result of exporters' role in helping economies adopt and master international best-practice technologies, thus being classified as a dynamic factor (Das 1998).

Exports of manufactures have risen as a proportion of total exports for all the listed economies (Table 7.3). In newly industrialising economies, they rose from 71 per cent in 1970 to 91 per cent in 2000, and for ASEAN, the average proportion of manufactured products in total exports increased from six to 76 per cent over the same period, representing a faster export growth rate than that in newly industrialising economies. During the same period, China nearly doubled its share of manufactured products in total exports, which accounted for 88 per cent of its total exports in 2000. A similar trend was observed for India whose share reached 79 per cent in 2000 .

\begin{tabular}{|c|c|c|c|c|}
\hline \multirow[t]{2}{*}{ Table 7.3} & \multicolumn{4}{|c|}{$\begin{array}{l}\text { Exports of manufactures as per cent of total exports, } \\
1970-2000 \text { (per cent) }\end{array}$} \\
\hline & 1970 & 1980 & 1990 & 2000 \\
\hline NIEs & 71.0 & 80.7 & 88.5 & 91.2 \\
\hline Hong Kong & 95.9 & 96.5 & 95.8 & 95.7 \\
\hline Korea & 76.6 & 89.9 & 93.6 & 90.8 \\
\hline Singapore & 30.5 & 53.9 & 72.8 & 86.4 \\
\hline Taiwan & 76.1 & 87.9 & 92.6 & 95.3 \\
\hline ASEAN-4 & 6.1 & 14.7 & 52.7 & 76.3 \\
\hline Indonesia & 1.4 & 2.4 & 35.5 & 57.1 \\
\hline Malaysia & 7.4 & 19.0 & 54.2 & 81.2 \\
\hline Philippines & 7.6 & 36.8 & 68.8 & 88.6 \\
\hline Thailand & 8.0 & 28.1 & 64.3 & 78.0 \\
\hline China & 45.1 & 46.9 & 73.5 & 88.4 \\
\hline India & 52.0 & 58.9 & 72.3 & 79.4 \\
\hline
\end{tabular}

Source: UN COMTRADE, International Economic Databank, The Australian National University, Canberra. 
Pattern and direction of East Asian trade

Table 7.4 outlines the trade (both export and import) relationships between Japan, NIEs, ASEAN, EU and elsewhere for a selection of the East Asian countries separately, 1980 compared to 2003. While the export share of Japan's exports to the United States continued to rise, the shares of NIEs exports to the United States (and to Japan except Hong Kong) fell over this period. The surge in China's export share to the United States reflected the fact that NIEs have been shifting their production bases to China to take advantage of the relatively low labour costs there. There was a substantial fall in export shares of most of NIE, ASEAN economies and China to Japan while both intra-NIEs and intra-ASEAN trade shares are on the rise. East Asian economies' export shares to European Union show a trend of declining with exception of Singapore and Indonesia.

With a few exceptions, most East Asian economies are recording falling shares of imports from the United States, Japan and European Union while their shares of import from NIEs and ASEAN economies are increasing. NIEs, especially, have become major suppliers for ASEAN countries at the expense of Japan. China's import shares from the United States, Japan and European Union are falling, while its shares from both NIEs and ASEAN countries are increasing. As for China-Japan bilateral trade, China's exports to Japan accounted for 14.7 per cent of its total exports while China's imports from Japan accounted for 20 per cent of its total imports.

Changing pattern of comparative advantage

Table 7.5 illustrates the process of changing comparative advantage by reference to individual commodities. Japan's export specialisation in labourintensive products (travel goods, clothing and footwear) was still above the global mean in 1970, but fell well below unity later, and virtually to zero by the end of the century. A corresponding rise occurred over the period in Japan's export specialisation in such capital-intensive products as machinery and electrical machinery. The NIEs' export specialisation in individual labour-intensive products reached a peak between 1970 and 


\section{Table 7.4 Overall patterns of East Asian external trade, 1980 and 2003}

Orientation of exports by selected East Asian countries (\% of total exports of each country)

\begin{tabular}{|c|c|c|c|c|c|c|c|c|c|c|c|c|}
\hline \multirow{2}{*}{$\begin{array}{l}\text { Exporting } \\
\text { countries }\end{array}$} & \multicolumn{2}{|c|}{ To the US } & \multicolumn{2}{|c|}{ To Japan } & \multicolumn{2}{|c|}{ To NIEs } & \multicolumn{2}{|c|}{ To ASEAN } & \multicolumn{2}{|c|}{ To EU-15 } & \multicolumn{2}{|c|}{ Elsewhere } \\
\hline & 1980 & 2003 & 1980 & 2003 & 1980 & 2003 & 1980 & 2003 & 1980 & 2003 & 1980 & 2003 \\
\hline apan & 24.2 & 28.2 & 0.0 & 0.0 & 10.7 & 17.5 & 7.0 & 10.0 & 15.1 & 17.1 & 42.9 & 27.2 \\
\hline ong Kong & 26.0 & 10.7 & 4.6 & 5.7 & 5.5 & 5.7 & 6.8 & 5.4 & 24.6 & 18.7 & 32.5 & 53.9 \\
\hline Forea & 25.7 & 19.8 & 16.9 & 9.9 & 6.0 & 8.7 & 4.8 & 7.4 & 16.3 & 13.6 & 30.4 & 40.6 \\
\hline ingapore & 12.4 & 13.9 & 8.0 & 6.8 & 9.1 & 15.6 & 22.1 & 25.1 & 13.1 & 14.4 & 35.2 & 24.3 \\
\hline Taiwan & 34.3 & 22.3 & 11.0 & 10.3 & 12.0 & 28.8 & 5.2 & 7.2 & 15.3 & 14.7 & 22.3 & 16.8 \\
\hline ndonesia & 19.6 & 14.4 & 49.2 & 21.9 & 13.4 & 18.8 & 1.3 & 7.3 & 6.6 & 13.3 & 9.9 & 24.4 \\
\hline Malaysia & 16.3 & 21.0 & 22.8 & 11.4 & 23.0 & 25.9 & 3.4 & 7.8 & 18.0 & 13.3 & 16.3 & 20.7 \\
\hline Philippines & 27.5 & 25.2 & 26.6 & 16.1 & 8.8 & 16.9 & 4.6 & 9.4 & 18.0 & 16.2 & 14.4 & 16.2 \\
\hline Thailand & 12.7 & 18.3 & 15.1 & 15.6 & 13.6 & 14.9 & 8.6 & 8.9 & 26.5 & 16.1 & 23.5 & 26.1 \\
\hline China & 5.4 & 26.7 & 22.2 & 14.7 & 26.3 & 23.1 & 4.3 & 3.9 & 14.7 & 14.5 & 27.1 & 17.1 \\
\hline
\end{tabular}

Origin of imports of selected East Asian countries (\% of total imports of each country)

\begin{tabular}{|c|c|c|c|c|c|c|c|c|c|c|c|c|}
\hline \multirow{2}{*}{$\begin{array}{l}\text { Importing } \\
\text { countries }\end{array}$} & \multicolumn{2}{|c|}{ From the US } & \multicolumn{2}{|c|}{ From Japan } & \multicolumn{2}{|c|}{ From NIEs } & \multicolumn{2}{|c|}{ From ASEAN } & \multicolumn{2}{|c|}{ From EU-15 } & \multicolumn{2}{|c|}{ Elsewhere } \\
\hline & 1980 & 2003 & 1980 & 2003 & 1980 & 2003 & 1980 & 2003 & 1980 & 2003 & 1980 & 2003 \\
\hline pan & 16.9 & 16.5 & - & - & 5.0 & 7.2 & 15.9 & 13.7 & 6.3 & 13.2 & 55.8 & 49.3 \\
\hline ong Kong & 10.9 & 7.1 & 21.1 & 13.6 & 15.7 & 13.3 & 3.5 & 7.0 & 11.8 & 9.6 & 37.0 & 49.4 \\
\hline orea & 21.3 & 16.8 & 25.5 & 20.7 & 2.3 & 5.1 & 5.7 & 8.5 & 7.4 & 10.4 & 37.9 & 38.5 \\
\hline ingapore & 12.5 & 14.5 & 15.9 & 12.1 & 4.9 & 6.2 & 24.2 & 28.9 & 11.0 & 11.2 & 31.5 & 27.1 \\
\hline Taiwan & 23.7 & 17.0 & 27.2 & 24.0 & 3.4 & 11.3 & 6.3 & 11.3 & 8.6 & 12.0 & 30.8 & 24.4 \\
\hline Indonesia & 12.4 & 7.8 & 30.0 & 17.1 & 15.7 & 18.5 & 3.6 & 8.0 & 13.9 & 13.6 & 24.4 & 34.9 \\
\hline Malaysia & 14.8 & 13.3 & 22.4 & 16.6 & 16.2 & 29.5 & 4.6 & 10.9 & 16.9 & 11.0 & 25.0 & 18.6 \\
\hline Philippines & 22.7 & 20.6 & 19.2 & 21.5 & 7.9 & 20.7 & 5.0 & 9.6 & 11.4 & 7.3 & 33.8 & 20.3 \\
\hline Thailand & 14.1 & 10.1 & 20.7 & 23.2 & 11.2 & 11.9 & 5.4 & 10.8 & 15.0 & 10.5 & 33.7 & 33.6 \\
\hline China & 19.3 & 10.3 & 26.1 & 20.2 & 3.8 & 18.6 & 2.3 & 9.1 & 16.8 & 14.8 & 31.5 & 27.0 \\
\hline
\end{tabular}

Note: ASEAN excludes Singapore; NIEs includes Singapore; For Taiwan, the data of 2003 is actually data of 2001 .

Sources: International Monetary Fund Direction of Trade Statistics, Washington DC; International Economic Databank, The Australian National University, Canberra. 


\section{Table 7.5 International comparison of shifting patterns of export} specialisation in selected industrial sectors, 1970-2000 (index of revealed comparative advantage)

\begin{tabular}{lccccccc}
\hline Machinery (SITC 71) & 1970 & 1975 & 1980 & 1985 & 1990 & 1995 & 2000 \\
China & 0.1 & 0.1 & 0.1 & 0.1 & 0.3 & 0.4 & 0.7 \\
Japan & 0.9 & 1.0 & 1.4 & 1.4 & 1.6 & 1.7 & 1.5 \\
NIEs & 0.1 & 0.2 & 0.4 & 0.5 & 0.8 & 1.0 & 1.4 \\
ASEAN & 0.1 & 0.2 & 0.2 & 0.4 & 0.8 & 1.2 & 1.4 \\
United States & 1.6 & 1.7 & 1.9 & 1.7 & 1.3 & 1.4 & 1.4
\end{tabular}

Electrical machinery (SITC 72)

$\begin{array}{llllllll}\text { China } & 0.2 & 0.2 & 0.2 & 0.3 & 0.7 & 0.9 & 1.1 \\ \text { Japan } & 2.1 & 1.9 & 2.5 & 2.2 & 2.1 & 1.9 & 1.6 \\ \text { NIEs } & 1.8 & 2.0 & 2.3 & 1.8 & 2.0 & 2.0 & 1.8 \\ \text { ASEAN } & 0.2 & 0.6 & 1.2 & 1.3 & 1.8 & 2.0 & 2.1 \\ \text { United States } & 1.2 & 1.3 & 1.5 & 1.4 & 1.3 & 1.2 & 1.2\end{array}$

Travel goods (SITC 83)

$\begin{array}{lrrrrrrr}\text { China } & 2.8 & 3.2 & 3.4 & 8.2 & 3.1 & 8.6 & 7.9 \\ \text { Japan } & 2.0 & 0.5 & 0.3 & 0.2 & 0.1 & 0.0 & 0.0 \\ \text { NIEs } & 8.9 & 14.9 & 16.2 & 9.7 & 6.5 & 2.1 & 0.8 \\ \text { ASEAN } & 0.4 & 0.7 & 0.4 & 0.3 & 1.2 & 1.1 & 1.2 \\ \text { United States } & 0.2 & 0.3 & 0.3 & 0.1 & 0.2 & 0.2 & 0.3\end{array}$

Clothing (SITC 84)

$\begin{array}{lrrrrrrr}\text { China } & 2.0 & 2.4 & 4.7 & 5.2 & 4.9 & 5.1 & 4.6 \\ \text { Japan } & 1.2 & 0.3 & 0.2 & 0.2 & 0.1 & 0.0 & 0.0 \\ \text { NIEs } & 13.3 & 14.2 & 10.1 & 6.8 & 4.2 & 2.1 & 1.7 \\ \text { ASEAN } & 0.3 & 0.6 & 0.9 & 1.1 & 1.8 & 1.4 & 1.2 \\ \text { United States } & 0.3 & 0.2 & 0.3 & 0.1 & 0.2 & 0.4 & 0.4\end{array}$

Footwear (SITC 85)

$\begin{array}{llllllll}\text { China } & 1.3 & 1.6 & 1.8 & 1.6 & 3.8 & 6.1 & 6.4 \\ \text { Japan } & 1.1 & 0.1 & 0.1 & 0.0 & 0.0 & 0.0 & 0.0 \\ \text { NIEs } & 3.6 & 6.2 & 7.8 & 6.5 & 5.1 & 1.1 & 0.3 \\ \text { ASEAN } & 0.2 & 0.2 & 0.4 & 0.3 & 1.3 & 2.1 & 1.1 \\ \text { United States } & 0.0 & 0.1 & 0.1 & 0.1 & 0.1 & 0.1 & 0.1\end{array}$

Note: ASEAN includes Singapore; NIEs excludes Singapore.

Source: Calculated using UN COMTRADE data, International Economic Databank, The Australian National University, Canberra. 
the early 1980s. It then fell away rapidly to well below unity for most products by the end of the century. The NIEs' export specialisation in machinery rose rapidly from low levels in 1970 to above unity at the end of the century. The NIEs export specialisation in electrical machinery was more stable, reflecting a wider range of relative factor requirements in production of these goods.

Individual labour-intensive products tended to rise in proportion to ASEAN countries' total exports until the mid 1980s. That their peaks were much lower than those in Northeast Asian economies is a reflection of the ASEAN economies' larger per capita endowments of natural resources. ASEAN export specialisation in electrical machinery exceeded unity by the 1980s and stabilised around 2 late in the 1990s. Export specialisation in machinery exceeded unity in the mid 1990s and continues to rise.

China's export specialisation in most labour-intensive products peaked at very high levels between the mid 1980s (travel goods and clothing) and the mid 1990s (footwear). It has tended to stabilise at the high levels. China's internal economic differentiation means that the country as a whole can retain comparative advantage in labour-intensive products for longer, as lower-cost labour from the inland replaces the labour from coastal China as the coastal provinces absorb more valuable skills and their labour costs rise. China's export specialisation in machinery rose rapidly from the mid1980s and was around unity, and rising, at the end of the century.

By contrast, US export specialisation in the products for which data are recorded in Table 7.5 remained relatively stable throughout the last several decades. It was consistently low for labour-intensive goods and high for machinery.

Table 7.6 sets out the net exports of manufactures of some selected Asia Pacific economies to Asia and the world for 1980-2000 (referred to as 'the ladder of development' by Leamer 1984). What matters here is not only the sign patterns, but also the magnitude of these net export figures. The data show that there is a clear pattern of trade specialisation in East Asian region with regard to manufactured products during the past two decades. 


\section{Table 7.6 Net exports of manufactures to Asia and the world, 1980, 1990 and 2000 (US\$ billion)}

\begin{tabular}{|c|c|c|c|c|c|c|c|c|}
\hline \multirow[b]{2}{*}{1980} & \multicolumn{2}{|c|}{ Labour-intensive } & \multicolumn{2}{|c|}{ Capital-intensive } & \multicolumn{2}{|c|}{ Machinery } & \multicolumn{2}{|c|}{ Chemicals } \\
\hline & Asia & World & Asia & World & Asia & World & Asia & World \\
\hline Australia & -0.70 & -1.40 & 0.70 & -0.11 & -0.05 & -6.02 & -0.10 & 0.16 \\
\hline China & 1.23 & 3.40 & -1.23 & -1.85 & -1.63 & -4.02 & -3.25 & -0.34 \\
\hline Hong Kong & -2.19 & 1.89 & 2.19 & -0.71 & -0.42 & -2.48 & -0.85 & -1.03 \\
\hline Indonesia & -0.07 & -0.08 & 0.07 & -1.26 & -0.06 & -3.52 & -0.11 & -0.90 \\
\hline Japan & -0.11 & 2.20 & 0.11 & 18.08 & -2.18 & 62.38 & -4.37 & 1.64 \\
\hline Korea & 0.61 & 5.59 & -0.61 & 1.20 & -0.66 & -1.54 & -1.32 & -1.12 \\
\hline Malaysia & -0.15 & 0.01 & 0.15 & -0.83 & -0.07 & -2.68 & -0.15 & -0.43 \\
\hline Singapore & -0.44 & -0.21 & 0.44 & -0.94 & -0.24 & -1.95 & -0.47 & -0.48 \\
\hline Thailand & 0.02 & 0.44 & -0.02 & -0.58 & -0.12 & -1.97 & -0.24 & -0.60 \\
\hline Taiwan & 0.87 & 5.32 & -0.87 & -0.14 & -0.95 & -0.76 & -1.89 & -1.09 \\
\hline United States & -7.62 & -7.50 & 7.62 & -5.29 & -0.34 & 24.83 & -0.67 & 5.82 \\
\hline \multicolumn{9}{|l|}{1990} \\
\hline Australia & -1.36 & -2.17 & 0.09 & -0.56 & -0.99 & -14.58 & 0.03 & -1.33 \\
\hline China & 5.47 & 13.42 & 0.87 & -0.66 & 0.61 & -11.10 & 0.14 & -0.95 \\
\hline Hong Kong & -14.19 & -7.18 & -0.96 & -2.08 & -7.38 & -14.61 & -1.27 & -3.82 \\
\hline Indonesia & 0.09 & 2.69 & -0.28 & -1.43 & -1.49 & -8.92 & -0.47 & -2.59 \\
\hline Japan & -6.22 & -7.71 & 5.95 & 10.81 & 42.27 & 152.43 & 5.44 & 2.96 \\
\hline Korea & 2.14 & 16.10 & 0.95 & 1.28 & 2.64 & 0.05 & 0.60 & -3.70 \\
\hline Malaysia & -0.50 & 0.71 & -0.28 & -1.68 & 0.21 & -4.55 & -0.32 & -1.35 \\
\hline Singapore & -1.42 & -0.32 & 0.02 & -1.76 & 0.03 & -0.68 & 1.08 & -0.04 \\
\hline Thailand & -0.27 & 3.56 & -0.70 & -2.91 & -0.61 & -8.90 & -0.26 & -2.01 \\
\hline Taiwan & 3.79 & 11.21 & 0.43 & 0.93 & 3.78 & 5.41 & 0.94 & -2.96 \\
\hline United States & -28.76 & -35.66 & -3.32 & -11.13 & -7.77 & -33.45 & 3.85 & 7.29 \\
\hline \multicolumn{9}{|l|}{2000} \\
\hline Australia & -2.60 & -3.43 & -0.57 & -1.51 & -6.26 & -24.98 & -0.26 & -0.33 \\
\hline China & 9.16 & 47.51 & -0.76 & 1.03 & -2.40 & -14.00 & -9.51 & -16.61 \\
\hline Hong Kong & -28.64 & -23.83 & -3.91 & -6.11 & -51.12 & -80.06 & -4.74 & -9.53 \\
\hline Indonesia & 0.69 & 8.63 & -0.44 & -1.14 & 2.34 & 0.08 & -0.79 & -2.25 \\
\hline Japan & -18.04 & -19.92 & 9.13 & 14.05 & 60.34 & 209.65 & 11.84 & 9.72 \\
\hline Korea & 3.31 & 13.32 & 2.41 & 3.01 & 11.53 & 37.93 & 6.41 & 2.92 \\
\hline Malaysia & -0.12 & 2.29 & -0.53 & -2.04 & 4.53 & 8.36 & -0.08 & -1.42 \\
\hline Singapore & -1.92 & -0.53 & -0.07 & -2.02 & 7.21 & 10.95 & 3.19 & 1.80 \\
\hline Thailand & -0.41 & 4.74 & -0.44 & -2.82 & 1.16 & 1.83 & 0.66 & -1.19 \\
\hline Taiwan & 6.73 & 11.92 & 2.95 & 5.44 & 9.58 & 16.15 & 3.12 & -3.04 \\
\hline United States & -54.80 & -79.23 & -11.01 & -21.30 & -70.92 & -180.70 & 4.53 & -3.81 \\
\hline
\end{tabular}

Source: UN COMTRADE, International Economic Databank, The Australian National University, Canberra. 
First, Japan together with the United States ranks at the top by exporting (net) the most advanced manufactured products, namely chemicals. Japan exports more to Asia than to the world in 1990 and 2000. Both countries are net importers of labour-intensive products, but a sharp difference between them is that Japan exports both capital-intensive and machinery products with high values, while the United States imports those products. This suggests that both countries retain comparative advantage in producing and exporting the most advanced manufactured products (chemicals) and that Japan has very strong comparative advantage in machinery and capitalintensive products.

Second, from 1980 to 1990 both Korea and Taiwan produced clear shifts in their net exports of capital-intensive and machinery from net importing to exporting these products. Such shifts provide some evidence of structural changes resulting from their changing pattern of comparative advantage. Korea and Taiwan have very similar sign patterns with regard to these four aggregates, exporting all these manufactured products except exports of chemicals to the world in the case of Taiwan. Another similarity between them is that both Korea and Taiwan export much smaller volumes of labour-intensive products to Asia than to the world (a clear sign of competition from other industrialising economies in the region).

Third, like Korea and Taiwan, Singapore exports both machinery and chemicals to both Asia and the world and capital-intensive products to Asia only in 1990 and 2000. However, the difference is that while both Korea and Taiwan are still exporting labour-intensive products to both Asia and the world (much less to Asia than to the world in terms of the values), Singapore has lost its comparative advantage in exporting this category of manufactured products to both Asia and the world. Since 1990, Hong Kong has become a net importer of all four manufactured aggregates.

Fourth, there are signs that Malaysia and Thailand are losing comparative advantage in labour-intensive product market in Asia, but gaining some comparative advantage in machinery by 2000. China and Indonesia are at the next rung on the ladder, namely exporting labour-intensive products to both Asia and the world. China is predominant in terms of its net export values of this product category, particularly to the world market, 
but it depends heavily on imports of machinery and chemicals from both Asia and the world by 2000 .

Fifth, Australia appears to have some comparative advantage in exporting capital-intensive and chemical products to Asia and the United States in both 1980 and 1990, but has been losing comparative advantage on both products by 2000. Australia is heavily dependent on imports of machinery and labour-intensive products from the world.

Finally, China has settled on the export structure ladder as a major exporter of labour-intensive manufactured products as determined by its pattern of factor endowment. This situation did not change much during the past two decades. What has changed noticeably is the magnitude of the exports of labour-intensive products from China to Asia and particularly to the world by 2000 .

Intra-industry trade and trade in components

An outstanding feature of the changing pattern of East Asian comparative advantage and trade specialisation is the huge expansion of trade in components. There is no longer a 'Japanese' car or 'Chinese' television set. Components are sourced from many countries to minimise total supply costs. This is a feature of the contemporary global economy, but it has been taken further in East Asia than in other major economic region (Garnaut and Song 2006).

Greater openness leads to the internationalisation of a manufacturing process in which many countries participate in different stages of the manufacture of a specified product. Trade in intermediate goods such as machinery parts and components is increasing. The process allows stages of production to be located where they can be undertaken most efficiently and at the lowest cost. As a result, countries are becoming more interdependent on each other (Yeats 1998) and global value chains (GVCs) offer significant opportunities to many Asian firms to take advantage of the potential benefits of globalisation (ADB 2003).

Closer regional economic integration emerges through market processes. A central feature of deeper East Asian economic integration has been the remarkable growth of trade in intermediate goods and components. China is now a major element in this process ( $\mathrm{Li}$ et al. 2007). Athukorala (2003) 
shows that in 2000, over 60 per cent of 'final exports' from developing Asia went to countries outside the East Asian region, especially North America and Europe, up from 55 per cent in 1992.

Table 7.7 shows that East Asia has been more deeply involved in fragmentation trade than other regions. Fragmentation trade is damaged more than conventional trade by transactions costs. For this and other reasons, it is damaged more than traditional trade by FTAs with their rules of origin. While trade in components is mainly within East Asia, a majority of the markets for the final products is still extra-regional. The fragmentation of the supply chain accelerates the growth of trade in components and makes the region more heavily dependent on extraregional trade for 'growth dynamism' than is suggested by data that does separate out the trade in components (Findlay 2003).

The large increases in fragmentation trade have been associated with rising intra-industry trade. By 2000, a few East Asian economies (Singapore, Korea, Taiwan, Thailand) had similar indexes of intra-industry trade with the world as a whole as the North American economies (Table 7.8). Most

\begin{tabular}{lccccc}
\hline Table 7.7 & \multicolumn{6}{l}{$\begin{array}{l}\text { Contribution of parts and components to export } \\
\text { growth, }\end{array}$} \\
& 1992-2000 (per cent) & & \\
\hline ChEAN & East Asia & EU-12 & NAFTA & World \\
Korea & 32.9 & 31.1 & 12.6 & 10.3 & 17.9 \\
Japan & 58.9 & 51.2 & 35.4 & 40.6 & 41.0 \\
Korea & 66.9 & 52.7 & 86.2 & 34.1 & 50.1 \\
Taiwan & 58.9 & 51.2 & 35.4 & 40.6 & 41.0 \\
Hong Kong & 67.6 & 50.8 & 37.5 & 54.9 & 47.4 \\
ASEAN & 29.2 & 21.6 & 34.9 & 8.8 & 16.3 \\
East Asia & 67.6 & 60.0 & 53.1 & 52.1 & 54.7 \\
EU-12 & 64.2 & 52.6 & 40.9 & 35.0 & 42.8 \\
NAFTA & 48.8 & 31.1 & 20.0 & 18.1 & 22.0 \\
United States & 74.4 & 55.8 & 34.2 & 23.3 & 29.9 \\
World & 73.9 & 55.9 & 34.8 & 30.7 & 38.1 \\
& 63.0 & 49.6 & 21.1 & 25.1 & 27.0
\end{tabular}

Source: Compiled from the data from Athukorala 2003. Product fragmentation and trade patterns in East Asia, Working Paper No. 21/2003. The Australian National University, Canberra: Table A-3 (B). 


\begin{tabular}{|c|c|c|c|c|c|c|c|c|}
\hline \multirow[t]{3}{*}{ Table 7.8} & \multicolumn{8}{|c|}{$\begin{array}{l}\text { Intra-industry trade indexes by destination, } 1985 \text { and } \\
2000\end{array}$} \\
\hline & \multicolumn{2}{|c|}{ East Asia } & \multicolumn{2}{|c|}{ EU-12 } & \multicolumn{2}{|c|}{ North America } & \multicolumn{2}{|c|}{ World } \\
\hline & 1985 & 2000 & $\overline{1985}$ & 2000 & 1985 & 2000 & 1985 & 2000 \\
\hline Australia & 11.9 & 25.7 & 10.5 & 23.4 & 12.2 & 27.9 & 22.4 & 36.6 \\
\hline New Zealand & 8.8 & 12.0 & 6.5 & 16.7 & 12.9 & 23.3 & 20.7 & 30.3 \\
\hline Japan & 17.7 & 42.5 & 32.9 & 43.1 & 21.2 & 42.1 & 19.8 & 41.6 \\
\hline Korea & 48.5 & 68.7 & 44.2 & 40.5 & 25.1 & 48.9 & 40.7 & 55.9 \\
\hline China & 23.2 & 49.9 & 10.0 & 42.7 & 7.6 & 32.6 & 21.3 & 47.6 \\
\hline Hong Kong & 24.8 & 11.5 & 30.7 & 20.1 & 20.8 & 18.2 & 45.7 & 19.6 \\
\hline Taiwan & 48.9 & 76.5 & 28.9 & 43.4 & 17.9 & 37.9 & 35.0 & 60.8 \\
\hline Singapore & 44.9 & 82.3 & 41.9 & 45.9 & 51.1 & 56.2 & 58.5 & 78.9 \\
\hline Indonesia & 10.1 & 32.8 & 3.9 & 20.1 & 1.9 & 14.8 & 15.1 & 34.0 \\
\hline Malaysia & 25.6 & 65.8 & 20.1 & 48.7 & 50.9 & 43.2 & 37.2 & 60.4 \\
\hline Thailand & 21.3 & 61.7 & 13.6 & 43.3 & 24.0 & 35.1 & 23.1 & 57.3 \\
\hline Philippines & 32.3 & 56.4 & 25.5 & 29.2 & 45.1 & 45.1 & 36.1 & 49.9 \\
\hline Vietnam & 2.2 & 19.0 & 3.2 & 8.1 & 0.3 & 7.7 & 7.1 & 17.6 \\
\hline EEC-12 & 43.5 & 50.9 & 97.6 & 92.9 & 53.3 & 67.2 & 78.9 & 86.6 \\
\hline United Kingdom & 39.4 & 41.7 & 62.7 & 74.1 & 50.8 & 65.2 & 72.2 & 79.9 \\
\hline Germany & 36.3 & 47.9 & 49.6 & 70.5 & 21.3 & 59.7 & 51.9 & 72.9 \\
\hline United States & 27.5 & 44.1 & 47.5 & 62.2 & 61.6 & 64.2 & 52.3 & 62.9 \\
\hline Canada & 13.3 & 17.2 & 25.7 & 39.5 & 61.3 & 63.4 & 63.3 & 66.0 \\
\hline Mexico & 6.1 & 12.2 & 8.7 & 30.7 & 33.8 & 59.1 & 31.9 & 60.5 \\
\hline
\end{tabular}

Source: UN Trade Data, International Economic Databank, The Australian National University, Canberra.

global indexes for the East Asian economies were moderately lower. Hong Kong was very low, reflecting characteristics of trade and industry structure rather than any failure of openness. Japan's global index had more than doubled between 1985 and 2000, but remained fairly low.

\section{Extent of East Asian integration}

Table 7.9 decomposes trade (exports plus imports) undertaken by countries in the various regions into percentages of total intra-regional and total inter-regional trade, which measures the extent of both intra- and interregional integration. 
Table 7.9 Intra-regional and inter-regional trade among actual and potential formal blocs, 1980-2003 (percentage of total trade)

\begin{tabular}{|c|c|c|c|c|}
\hline Pole & 1980 & 1990 & 2000 & 2003 \\
\hline \multicolumn{5}{|l|}{ North America } \\
\hline Intra-regional & 32.3 & 37.6 & 47.4 & 46.4 \\
\hline With European Union & 18.8 & 20.0 & 15.6 & 16.7 \\
\hline With East Asia & 24.9 & 35.4 & 31.6 & 31.4 \\
\hline With ASEAN & 3.5 & 4.2 & 5.1 & 4.7 \\
\hline With Australia and New Zealand & 1.4 & 1.5 & 0.9 & 0.9 \\
\hline \multicolumn{5}{|l|}{ European Union } \\
\hline Intra-regional & 56.6 & 64.6 & 60.2 & 60.9 \\
\hline With North America & 8.2 & 8.4 & 10.1 & 9.1 \\
\hline With East Asia & 32.5 & 38.9 & 37.4 & 37.3 \\
\hline With ASEAN & 1.1 & 1.5 & 2.1 & 1.9 \\
\hline With Australia and New Zealand & 0.7 & 0.7 & 0.6 & 0.6 \\
\hline \multicolumn{5}{|l|}{ East Asia } \\
\hline Intra-regional & 35.2 & 44.2 & 51.4 & 51.2 \\
\hline With North America & 21.9 & 25.6 & 22.1 & 20.1 \\
\hline With European Union & 12.0 & 16.3 & 13.7 & 13.9 \\
\hline With ASEAN & 12.6 & 11.4 & 14.0 & 14.7 \\
\hline With Australia and New Zealand & 3.7 & 3.2 & 2.5 & 2.7 \\
\hline \multicolumn{5}{|l|}{ ASEAN } \\
\hline Intra-regional & 16.9 & 17.4 & 22.6 & 23.2 \\
\hline With North America & 16.1 & 18.5 & 18.5 & 16.7 \\
\hline With European Union & 13.0 & 15.8 & 12.9 & 12.7 \\
\hline With East Asia & 53.0 & 55.5 & 55.5 & 55.9 \\
\hline With Australia and New Zealand & 3.1 & 2.7 & 2.6 & 3.0 \\
\hline \multicolumn{5}{|l|}{ ANZ } \\
\hline Intra-regional & 6.2 & 7.5 & 7.6 & 8.1 \\
\hline With North America & 18.4 & 19.9 & 17.7 & 15.1 \\
\hline With European Union & 20.1 & 20.1 & 17.0 & 19.8 \\
\hline With East Asia & 45.1 & 51.0 & 52.7 & 53.1 \\
\hline With ASEAN & 7.4 & 7.9 & 12.1 & 12.3 \\
\hline
\end{tabular}

Notes: ASEAN=Association of Southeast Asian Nations; EU=European Union; North America Pole: US, Canada, Mexico; East Asia Pole: Malaysia, Hong Kong, Indonesia, Japan, South Korea, China, Taiwan, Singapore, and the Philippines; ASEAN includes Singapore.

Sources: International Monetary Fund, Direction of Trade Statistics, Washington DC;

International Economic Databank, The Australian National University, Canberra. 
Table 7.10 shows that there are generally increasing trends of intraregional trade for all the blocs (except the European Union) across time. By 2003, the level of intra-regional trade is highest in the EU (60 per cent) followed by East Asia (51 per cent) and then North America (46 per cent). The region of ASEAN, a sub-set of East Asia, is not highly integrated in terms of intra-regional trade, although the trend is increasing. Australia and New Zealand have a relatively low level of intra-regional integration compared with other regions. In comparison with the rising trend of intraregional trade, inter-regional trade tends to fall for many regional blocs, for example for North America trade with both the EU and East Asia. However, East Asia has had the highest level of inter-regional trade with North America followed by its trade with EU, suggesting a high level of interdependence between the two regions. Australia and New Zealand have a highest level of inter-regional trade with East Asia (53 per cent compared with their trade share with the EU of 19 per cent and North America of 15 per cent).

Table 7.10 allows us to assess the extent to which the expansion of East Asian inter-regional and intra-regional trade has simply reflected the increase in scale of East Asia's trade with the rest of the world, and the extent to which it has involved changes in trade intensity with one or other set of partners (Garnaut and Song 2006). It does this through the presentation of intensity indexes as originally developed by Kojima (1964). It also breaks down the intensity index into complementarity and bias indexes, following Drysdale (1969) (see also Drysdale and Garnaut 1982). The latter step allows assessment of the extent to which changes in intensity of trade reflect respectively a closer match of the commodity composition of the two partners' trade, relative to their trade with the rest of the world, and the extent to which it resulted from changes in intensity of trade commodity-by-commodity.

Between 1985 and 2000, the intensity of intra-regional trade fell in East Asia, but rose in North America and Western Europe. Relative to the respective regions' shares in world trade, East Asia has come to trade relatively less within its own region, and the other two regions relatively more. Complementarity in intra-regional trade rose in East Asia, remained steady in Europe, and fell in North America. 
Table 7.10 Bias, complementarity and intensity indexes for major country groups, 1985 and 2000

\begin{tabular}{|c|c|c|c|c|c|c|c|c|c|c|c|c|}
\hline \multirow[b]{2}{*}{$\begin{array}{l}\text { Reporter } \\
\text { Type }\end{array}$} & \multicolumn{2}{|c|}{$\begin{array}{l}\text { Australia and } \\
\text { New Zealand }\end{array}$} & \multicolumn{2}{|c|}{ East Asia } & \multicolumn{2}{|c|}{ ASEAN } & \multicolumn{2}{|c|}{ EU-12 } & \multicolumn{2}{|c|}{$\begin{array}{l}\text { North } \\
\text { America }\end{array}$} & \multicolumn{2}{|c|}{$\begin{array}{c}\text { Rest } \\
\text { of world }\end{array}$} \\
\hline & 1985 & 2000 & 1985 & 2000 & 1985 & 2000 & 1985 & 2000 & 1985 & 2000 & 1985 & 2000 \\
\hline \multicolumn{13}{|c|}{ Australia and New Zealand } \\
\hline Bias & 8.3 & 9.0 & 1.8 & 1.7 & 2.6 & 2.3 & 0.4 & 0.3 & 0.9 & 0.6 & 1.1 & 1.1 \\
\hline Complementarity & 0.5 & 0.7 & 1.4 & 1.2 & 0.7 & 0.8 & 1.0 & 1.0 & 0.5 & 0.7 & 1.0 & 1.2 \\
\hline Intensity & 3.9 & 6.3 & 2.5 & 2.0 & 1.8 & 1.9 & 0.4 & 0.3 & 0.5 & 0.4 & 1.1 & 1.3 \\
\hline \multicolumn{13}{|l|}{ East Asia } \\
\hline Bias & 1.4 & 1.2 & 1.6 & 1.2 & 2.0 & 1.4 & 0.3 & 0.4 & 1.1 & 0.7 & 0.6 & 0.5 \\
\hline Complementarity & 1.1 & 1.0 & 1.1 & 1.3 & 1.1 & 1.5 & 0.9 & 1.0 & 1.1 & 1.1 & 1.0 & 0.9 \\
\hline Intensity & 1.6 & 1.2 & 1.7 & 1.6 & 2.2 & 2.0 & 0.3 & 0.4 & 1.3 & 0.8 & 0.6 & 0.4 \\
\hline \multicolumn{13}{|l|}{ ASEAN (6) } \\
\hline Bias & 2.0 & 2.2 & 2.5 & 1.6 & 4.1 & 2.5 & 0.4 & 0.5 & 1.0 & 0.7 & 0.5 & 0.6 \\
\hline Complementarity & 0.8 & 0.9 & 1.2 & 1.3 & 1.3 & 1.5 & 0.9 & 0.9 & 0.9 & 1.0 & 0.9 & 0.9 \\
\hline Intensity & 1.6 & 2.0 & 3.1 & 2.2 & 5.2 & 3.8 & 0.3 & 0.4 & 0.9 & 0.7 & 0.5 & 0.5 \\
\hline \multicolumn{13}{|l|}{ EU-12 } \\
\hline Bias & 0.4 & 0.4 & 0.2 & 0.2 & 0.2 & 0.2 & 1.0 & 1.1 & 0.3 & 0.3 & 0.8 & 1.0 \\
\hline Complementarity & 1.1 & 1.1 & 0.9 & 0.9 & 1.0 & 0.9 & 1.1 & 1.1 & 1.0 & 1.0 & 1.1 & 1.1 \\
\hline Intensity & 0.5 & 0.4 & 0.2 & 0.2 & 0.2 & 0.2 & 1.1 & 1.2 & 0.3 & 0.3 & 0.8 & 1.1 \\
\hline \multicolumn{13}{|l|}{ North America } \\
\hline Bias & 0.9 & 0.7 & 0.9 & 0.6 & 0.7 & 0.6 & 0.4 & 0.3 & 1.1 & 1.4 & 0.6 & 0.4 \\
\hline Complementarity & 1.2 & 1.1 & 1.0 & 0.9 & 0.9 & 1.0 & 1.0 & 1.0 & 1.3 & 1.1 & 1.0 & 1.0 \\
\hline Intensity & 1.0 & 0.7 & 0.8 & 0.6 & 0.6 & 0.5 & 0.4 & 0.3 & 1.4 & 1.6 & 0.6 & 0.4 \\
\hline \multicolumn{13}{|l|}{ Rest of world } \\
\hline Bias & 0.3 & 0.3 & 0.3 & 0.4 & 0.3 & 0.4 & 0.8 & 0.9 & 0.5 & 0.5 & 1.2 & 1.4 \\
\hline Complementarity & 0.8 & 1.0 & 1.2 & 1.0 & 1.1 & 0.9 & 1.0 & 1.0 & 0.9 & 1.0 & 1.1 & 1.1 \\
\hline Intensity & 0.3 & 0.3 & 0.4 & 0.4 & 0.3 & 0.4 & 0.8 & 0.9 & 0.4 & 0.5 & 1.2 & 1.5 \\
\hline
\end{tabular}

Source: Garnaut, R. and Song, L., 2005. Truncated globalisation: the fate of the Asia Pacific economies?, in Hadi Soesastro and Christopher Findlay (eds), Reshaping the Asia Pacific Economic Order, Routledge, London: Table 7.

\section{China in East Asian economic integration}

In his discussion of the ladder hypothesis and multiple export catch-up of the East Asian economies, Pearson (1994) raised several questions about China's position and potential in the process of industrial and trade transformation taking place in the region. The delayed entrance of the 
People's Republic of China into this dynamic process in the late 1970s poses interesting questions. Where has China settled on the export structure ladder, and how rapidly will it climb? Are Korean and Taiwanese export structures sufficiently sophisticated to escape pressure from China from below? Will the entrance of China slow the progress of ASEAN economies as exporters? Does the sheer size of the Chinese economy and its export potential add a new dimension? (Pearson 1994:37)

The emergence of China as a major exporter of manufactures in the 1980 s and especially the 1990s has intensified the competitive impacts on other East Asian economies, thereby, accelerating the pace and depth of the structural adjustment in the regional economy. For example, competition between China and other Asian countries is likely to increase as China's relatively cheap and productive workforce provides it with comparative advantages on world markets across a range of labour-intensive products.

China has an important place in the sale of many labour-intensive products in world markets, which are similar to those produced in the ASEAN economies (Xu and Song 2000). China has also increased its shares of world total labour-intensive manufactured exports from 1970 to 2000 (Figure 7.1). In contrast, the shares of NIEs in world total labour-intensive exports have been declining rapidly, while the gap between China and ASEAN in terms of their shares in world total has been widening especially since the early 1990s (Figure 7.1).

Progress in structural adjustment in these economies can be seen from the declining shares of labour-intensive products in their total exports from 1970 to 2000 (Figure 7.2). However, the task of structural adjustment seems more pressing for the latecomers.

\section{Competitive relationships and structural adjustments}

The competitive relationships between the three competing economies of China, ASEAN and NIEs can be seen by examining the more detailed two-digit SITC data. Table 7.11 presents the figures of two digit-SITC categories falling into the advantage or disadvantage groups for each 
Figure 7.1 Changing share of some East Asian economies in world total labour-intensive manufactured exports, 19702000 (per cent)

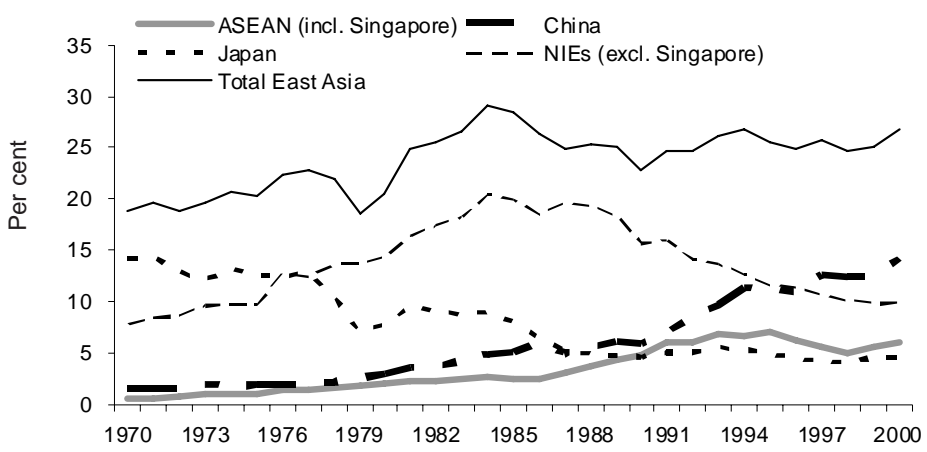

Source: Authors' calculation using UN COMTRADE, International Economic Databank, The Australian National University, Canberra.

Figure 7.2 Share of labour-intensive products in total exports, 1970-2000 (per cent)

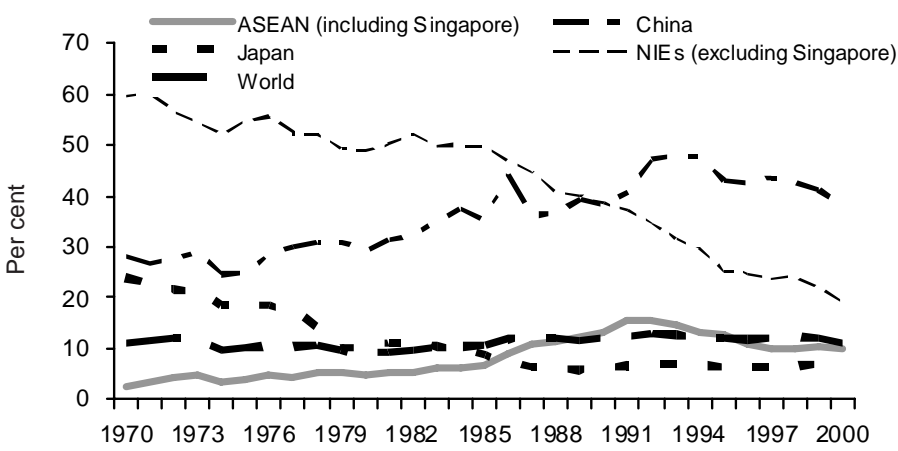

Source: Calculated using UN COMTRADE data, International Economic Databank, The Australian National University, Canberra. 


\section{Table 7.11 Competitive advantage and disadvantage with the United States, 1987-2000}

Number of two-digit SITC

categories which had

ASEAN

23

35

3

61
China

35

24

1

60
NIEs

16

40

5

61

Source: Song, L., 2004. The export competitiveness of ASEAN, China and the East Asian NIEs, 1987-2000, paper presented at the international conference on Rising China and the East Asian Economy, The Korea Institute for International Economic Policy (KIEP), Seoul, Korea:19-20: Table 13.

competing economy. The strong competitive advantage of China is also evident at the two-digit level of SITC categories, followed by ASEAN and then NIEs.

Increased competition has forced both China and other Asian countries to make the necessary structural adjustments by upgrading their industries, especially towards producing more capital- and technology-intensive products. This competitive pressure is particularly important in the relationship between China and the NIEs, as China's rising trade has forced the NIEs to move more quickly in upgrading their industrial structures in order to sustain a rapid growth of exports (Song 2004).

Table 7.12 shows that 68 per cent of NIE exports and 60 per cent of ASEAN exports, but only 44 per cent of Chinese exports in 1987 were in sectors that grew above average from 1987 to 2000. The fact that 68 per cent of NIE exports were concentrated in fast-growing categories suggests that NIEs had considerable structural advantage compared with China and ASEAN. The strong structural advantage of NIEs can also be found at the two-digit level of SITC codes. Table 7.13 shows the number of SITC categories that fell into either the structural advantage or structural disadvantage groups. At this level, the structural advantage for the NIEs is obvious with 45 categories that fell into the structural advantage group compared with 22 for ASEAN and only 11 for China. 


\section{Table 7.12 Proportion of exports to the United States by SITC category}

\begin{tabular}{|c|c|c|c|c|c|}
\hline \multirow[t]{2}{*}{ Commodity } & \multirow{2}{*}{$\begin{array}{l}1987-2000 \\
\text { Reference growth } \\
\text { (per cent) }\end{array}$} & \multirow{2}{*}{$\begin{array}{l}\text { Relative } \\
\text { growth }\end{array}$} & \multicolumn{3}{|c|}{$\begin{array}{l}\text { Proportion of } 1987 \text { exports } \\
\text { (per cent) }\end{array}$} \\
\hline & & & ASEAN & China & NIE \\
\hline 0 - Food & 7.16 & Fast & 7.66 & 2.37 & 1.01 \\
\hline 1 - Beverages & 7.45 & Fast & 0.14 & 0.08 & 0.04 \\
\hline 2 - Crude materials & 3.53 & Slow & 3.24 & 1.24 & 0.36 \\
\hline 3 - Fuels & 0.99 & Slow & 3.41 & 2.34 & 0.48 \\
\hline 4 - Vegetable oil & 3.07 & Slow & 1.35 & 0.02 & 0.01 \\
\hline 5 - Chemicals & 12.61 & Fast & 0.92 & 3.71 & 1.67 \\
\hline 6 - Manufactures & 6.75 & Fast & 6.94 & 12.87 & 9.59 \\
\hline 7 - Machinery and transport equ & pment 12.42 & Fast & 44.42 & 25.14 & 56.07 \\
\hline 8 - Miscellaneous manufactures & 5.43 & Slow & 28.02 & 52.18 & 30.37 \\
\hline 9 - Not classified & -3.00 & Slow & 3.90 & 0.06 & 0.38 \\
\hline Average & 5.64 & & 100.00 & 100.00 & 100.00 \\
\hline
\end{tabular}

Source: Song, L., 2004. The export competitiveness of ASEAN, China and the East Asian NIEs, 1987-2000, paper presented at the international conference on Rising China and the East Asian Economy, The Korea Institute for International Economic Policy (KIEP), Seoul, Korea:19-20: Table 10.

\section{Table 7.13 Structural advantage and disadvantage, 1987-2000}

\begin{tabular}{lccc}
\hline Number of two-digit SITC categories which had & ASEAN & China & NIE \\
Structural advantage & 22 & 11 & 45 \\
Structural disadvantage & 39 & 49 & 16 \\
Total & 61 & 60 & 61
\end{tabular}

Source: Song, L., 2004. The export competitiveness of ASEAN, China and the East Asian NIEs, 1987-2000, paper presented at the international conference on Rising China and the East Asian Economy, The Korea Institute for International Economic Policy (KIEP), Seoul, Korea:19-20: Table 11.

The China dimension of the process of East Asian economic integration can be elucidated through the following analysis. First, the economic reform and policy of opening up the economy has made China increasingly part 
of East Asian economic integration, which is reflected in the significant shifts in production and the trade structures of these economies. The fundamental causes for such shifts lie in differences in the patterns of factor endowments and levels of development in these economies. In case of China, the result has been largely due to a convergence of its patterns of factor endowments and trade, which accounts for the rapid expansion of China's trade share in labour-intensive manufactured exports and are apparent in its increasing trade share in some capital-intensive manufactured exports in the regional and world markets (Song 1996b).

Second, the process of industrial and trade transformation in the East Asian region that started decades ago has been very dynamic. Participation in this process by China since the beginning of its reform in the late 1970 s has injected new forces into this transformation, increasing the specialisation in manufactured production and exports. As a result, East Asia economies, with an increase in intra-regional trade and investment and a larger share in world trade, are emerging as a new economic centre in the world economy.

Third, China's economic integration with the East Asian economies has benefited both China and other East Asian economies in terms of creating a bigger market for export products and taking advantage of scale economies and increased trade and investment opportunities. But it also poses challenges to the economies in the region. These could take the form of increased competition for labour-intensive manufactures exporters, for some capital-intensive manufactures exporters in the next stage of development of East Asian economy as well as competition for attracting foreign investment.

Fourth, the trade outlook for the East Asian industrialising economies will depend on future changes in their patterns of factor endowments. It also depends on both the trade policies they apply domestically and those pursued by their trading partners abroad. In this context, the industrialising economies of East Asia have a large stake in continuing their strategy of trade and investment liberalisation in their domestic economies and in the maintenance of open, rules-oriented international trade and investment regimes as well as the further developments of regional and multilateral forums for trade negotiations (Balassa and Noland 1994). 
Prospects for the future East Asian trade and development

How has East Asia's rapid growth in output and trade, and tendency to trade globally rather than within its own region (to a greater extent than North America and Europe), affected the rest of the world economy?

The main effect is to expand the potential gains from trade in the rest of the world. This follows simply from the expanded scope for other economies to specialise in supply of goods and services in which their comparative advantage is strong.

The utilisation of these opportunities has required acceptance of structural change. The relatively steady East Asian share of global markets for the products in which the region's export specialisation has been strongest, labour-intensive manufactures, suggests that the costs of structural change for the world outside East Asia have not been high since the early 1980s, that is, since the early entry of East Asia into the international economy (see also Garnaut and Huang 2000). The pressures for continuing structural change of a radical kind have been greatest within East Asia itself, as identified in this chapter.

The skewed nature of East Asia's resource endowment relative to the rest of the world, with extreme relative scarcity of land and other natural resources, has made East Asia disproportionately and increasingly an importer of resource-based products. This has reduced the pressures on these old industries to decline in the industrial economies of the North Atlantic.

The East Asian economies will certainly continue to benefit from those contributing factors to East Asian trade and development, such as high savings, accumulation of both physical and human capital, a relatively stable market environment, liberalisation of domestic economies, inflows of FDI, geographic closeness, and various forms of economic cooperation.

However, there are a number of factors that have the potential to affect adversely the trade flows to and from East Asia, which include the weak growth and rising protectionism of the developed markets, instabilities of the financial systems, exchange rate volatility, weak domestic institutions, national policy of protection particularly with respect to those 'sensitive sectors', lack of progress in the multilateral trade negotiations and confusion about forms of forging regional economic cooperation (groupings). 
The emergence of China as a major exporter of manufactures has been causing anxieties among other East Asian economies. With the rising degree of interdependence among the East Asian economies, there are also issues of geopolitics such as Japan-China bilateral relations and their respective relations with other East Asian economies such as ASEAN.

The regional economies are now at a stage where there is no basis for confidence that the continued strengthening of an open multilateral trading system will provide continually expanding access on a non-discriminatory basis for exports from each Asia Pacific economy's most productive industries, as they evolve over time. The old Western Pacific doctrines of 'open regionalism', and a conceptual framework within which unilateral trade liberalisation, regional cooperation within ASEAN and APEC, and multilateral liberalisation under the aegis of the WTO, have gone, and no conceptual or institutional alternative has arisen to provide confidence that the international environment will support continued rapid, internationally oriented growth. This was pointed out by Garnaut and Song (2004), who argue the following in responding to the newly resurgent interest in forming various bilateral and sub-regional trading arrangements.

First, the new pattern of bilateral and sub-regional preferences would truncate the process of increasingly precise specialisation in the supply of inputs into final products assembled in one or other of the Asia Pacific economies, because of the rules of origin.

Second, the contemporary regionalisation and globalisation of production would also be damaged by the transaction costs associated with monitoring and enforcing rules of origin, even in cases in which the domestic-plus-partner value-added were able to meet the tests.

Third, the proliferation of FTAs is a problem for adjustment to the rise of China, because it concentrates adjustment excessively in countries which have FTAs with China and also in those which do not have FTAs with third countries. It denies the great advantage of multilateral trade on a global basis, in that it diffuses pressures for adjustment throughout the global economy.

Fourth, using FTAs to separate third countries from East Asian dynamism, whether in East Asia or adjoining third countries, reduces 
their exposure to opportunities for rising living standards. This is likely to be most damaging to potential suppliers of the natural-resource based products in which China's comparative disadvantage is most pronounced, and especially of the agricultural industries in which trade distortion is endemic.

Finally, the trade-off between costs of adjustment and gains from trade through the rise of China is affected by the presence of FTAs. For the world as a whole, the trade-off between adjustment costs and gains from trade is more favourable if the movement is toward specialisation according to global comparative advantage, as it is modified by growth and structural change in individual economies.

Multilateral trading arrangements or wider regional groupings, rather than narrowly focused and complex and discriminatory bilateral trading arrangements, are conductive to the East Asian objective of sustaining fast export growth. In the case of China, what it essentially requires is not a number of narrowly focused bilateral arrangements or exclusive regional groupings that are discriminatory in nature. What it needs is wider open trading arrangements, ideally in global scope, that are consistent with non-discriminatory principles in international trade. As pointed out by Drysdale (1988), 'discriminatory trade regimes are likely to be damaging to the interests of East Asia and Pacific countries' (Drysdale 1988:36).

Thus, the task of 'institutional integration' remains a big challenge for the East Asian and Pacific economies. We close by quoting the conclusion by Drysdale in his book entitled, International Economic Pluralism: Economic Policy in East Asia and the Pacific

the Pacific belongs to no single nation-not Japan, despite its new-found economic power, nor China, despite the scale of its industrial promise, nor, any longer, America. The responsibilities of Pacific economic policy leadership are bound to be developed as shared responsibilities. The huge and rewarding task of establishing a degree of intimacy among the heterogeneous nations of the Pacific, upon which confident policy strategies can be promulgated and executed in support of international systemic objectives, is a challenge to which Pacific countries are now fortunately at last beginning to turn (Drysdale 1988:260). 


\section{References}

Asian Development Bank, 2003. Asian Development Outlook, Asian Development Bank, Manila.

Athukorala, P., 2003. Product fragmentation and trade patterns in East Asia, Working Paper No. 2003/21, The Australian National University, Canberra.

Balassa, B. and Noland, M., 1994. 'Prospects of trade and regional cooperation of the industrialising economies of East Asia', in S.C. Yang (ed.), Manufactured Exports of East Asian Industrialising Economies: possible regional cooperation, M.E. Sharpe, New York: pp.

Bradford, C.I. and Branson, W. H., 1987. 'Patterns of trade and structural change', in C.I. Bradford and W.H. Branson (eds), Trade and Structural Change in Pacific Asia, The University of Chicago Press, Chicago and London.

Das, Dilip K., 1998. 'Changing comparative advantage and the changing composition of Asian exports', The World Economy, 21(1):121-40.

Drysdale, P., 1969. 'Japan, Australia and New Zealand: the prospects for Western Pacific economic integration', Economic Record, 45 (111):321-42.

- 1988. International Economic Pluralism: economic policy in East Asia and the Pacific, Allen \& Unwin, Sydney.

Drysdale, P., and Garnaut, R., 1982. 'Trade intensities and the analysis of bilateral trade flows in a many-country world', Hitotsubashi Journal of Economics, 22(2).

—, 1993. 'The Pacific: an application of a general theory of economic integration', in Fred Bergsten and Marcus Noland (eds), Pacific Dynamism and the International Economic System, Institute for International Economics, Washington, DC:183-224.

Drysdale, P., 2003. Regional Cooperation in East Asia and FTA Strategies', Presentation to IIPS Conference on Building a Regime of Regional Cooperation in East Asia and the Role which Japan Can Play, Tokyo, 2-3 December.

Findlay, C., 2003. 'China in the world economy: the FTA strategy', in R. Garnaut and L. Song (eds), China: New Engine of World Growth, Asia Pacific Press, The Australian National University, Canberra:176-88. 
Garnaut, R. and Anderson, K., 1980. 'ASEAN export specialisation and the evolution of comparative advantage in the Western Pacific region', in R. Garnaut (ed.), ASEAN in a Changing Pacific and World Economy, ANU Press, Canberra:374-412.

Garnaut, R. and Huang, Y., 2000. 'China and the future of the international trading system', in P. Drysdale and L. Song (eds), China's Entry to the WTO: Strategic Issues and Quantitative Assessments, Routledge, London:7-29.

Garnaut, R. and Song, L., 2006. 'Truncated globalisation: the fate of the Asia Pacific economies?', in Hadi Soesastro and Christopher Findlay (eds), Reshaping the Asia Pacific Economic Order, Routledge, London:46-81.

Kojima, K., 1964. 'The pattern of international trade among advanced countries', Hitotsubashi Journal of Economics, 5(1).

Krueger, A.O., 1997. 'Trade policy and economic development: how we learn', American Economic Review, 87(1):1-22.

Leamer, E.E., 1984. Sources of International Comparative Advantage: Theory and Evidence, The MIT Press, Cambridge, Massachusetts.

Li, K., Song, L. and Zhao, X., 2007. 'Component trade and China's global economic integration', in R. Garnaut and L. Song (eds), China: Linking Markets for Growth, Asia Pacific Press, The Australian National University, Canberra: 71-94.

Pearson, C.S., 1994. 'The Asian export ladder', in Shu-Chin Yang (ed.) Manufactured Exports of East Asian Industrialising Economies: Possible Regional Cooperation, M.E. Sharpe, New York.

Song, L., 1996a. Changing Global Comparative Advantage: Evidence from Asia and the Pacific, Addison-Wesley, Melbourne.

— $1996 \mathrm{~b}$. 'Institutional change, trade composition and export supply potential in China', in M. Guitian and R. Mundell (eds), Inflation and Growth in China, International Monetary Fund, Washington, DC: $190-225$.

, 2004. 'The export competitiveness of ASEAN, China and the East Asian NIEs, 1987-2000', paper presented at the international conference on Rising China and the East Asian Economy, The Korea Institute for International Economic Policy (KIEP), Seoul:19-20. 
Xu, X.P. and Song, L., 2000. 'Export similarity and the pattern of East Asia development, in P. Lloyd and X.G. Zhang (eds), China in the Global Economy, Edward Elgar, Cheltenham:145-164.

Yeats, Alexander, 1998. Just how big is global production sharing?, The World Bank, Policy Research Working Paper, No. 1871, World Bank, Washington DC. 